\title{
TRANSGENERATIONAL EFFECT: REMEMBERED ATTACHMENT, ATTACHMENT TO PARTNERS AND BONDING TOWARDS NEWBORNS
}

\author{
Katarína Greškovičová, \& Kristína Mrázková \\ Faculty of Psychology, Paneuropean University (Slovakia)
}

\begin{abstract}
There is no doubt that emotional relationships are very important. Attachment theory describes functioning in these relationships through inner working models that guide expectations and behaviours in the relationships. Therefore, we can suppose that attachment affect actual relationships toward partners as well as own children since both are emotional-relationship objects. Our aim was to explore transgenerational effect of attachment (what was I given, what do I share with my partner, what do I give to my newborn). We had three objectives- to find out whether remembered attachment is a predictor of attachment in close relationships and bonding; whether attachment in close relationships is a predictor of bonding, and whether there are differences between men and women in attachment and bonding. Our sample consisted of fathers $(n=27)$ and mothers $(n=73)$ who recently gave birth. Participants of age between 21 and 46 years were approached at obstetrics and gynaecology clinic in Bratislava, Slovakia. They filled in 3 self-administered questionnaires: sEMBU (remembered attachment), ECR-R (attachment in close relationships), and MIBQ (bonding towards infant). The results showed weak to moderate correlations among remembered attachment and attachment in close relationships/bonding. Mother's emotional warmth in remembered attachment predicts both avoidance (adjusted $\mathrm{R}^{2}=.091, \beta=-.317, \mathrm{p}=.001$ ) and anxiety (adjusted $\mathrm{R}^{2}=.045$, $\beta=-.233, \mathrm{p}=.019$ ) in attachment in close relationships. Mather's emotional warmth (adjusted $\mathrm{R}^{2}=.086$, $\beta=.309, \mathrm{p}=.002$ ) and rejection (adjusted $\mathrm{R}^{2}=.051, \beta=-.246, \mathrm{p}=.014$ ) in remembered attachment predict acceptance of parental role in bonding. Attachment in close relationships did not prove to be a predictor of bonding. As to differences between men and women, we found that men felt more rejected by mother than women in remembered attachment $\left(\mathrm{r}_{\mathrm{m}}=.215\right)$, men scored higher in both avoidance $\left(\mathrm{r}_{\mathrm{m}}=.210\right)$ and anxiety $\left(\mathrm{r}_{\mathrm{m}}=.209\right)$ than women in attachment in close relationships, and women were more prepared for nurturing the infant than men in bonding $\left(\mathrm{r}_{\mathrm{m}}=.272\right)$. The differences were small though. We see several limits among which self-reported instruments, new questionnaire MIBQ, relatively big age range of our participants, smaller sample of men are the most serious ones. Even though, we consider our research to be important in slightly clarifying an importance of remembered emotional warmth of mother in functioning in actual relationships.
\end{abstract}

Keywords: Bonding, attachment, parent, newborn, transgenerational transmission.

\section{Introduction}

Attachment stems from child's innate need to attach to a primary person (Bowlby, 2010). From a life span perspective (Hennelová, 2014), attachment behaviour manifests all one's life and its main goal- feeling of security- is constant (Bowlby, 2010). Only the needs of the attachment, the event of its triggering, the forms of acquiring a closeness and attachment figures are subjects to change (Mikulincer \& Shaver, 2007). Attachment runs on "inner working models" that store scenes with attachment situations and they create interpretation filters that affect behaviour, thinking, and perception in attachment relationships (Bretherton \& Munholland, 2008). One of the vexing questions in attachment research dedicates to intergenerational transmission of attachment, and especially on its effect size (Verhage et al., 2016).

Intergenerational/transgenerational transmission involves two or three objects (generations) of research sample (mothers/fathers and their children) and the results confirmed concordance of attachment styles (Behrens et al., 2016; Bretherton \& Munholland, 2008; Feeney \& Woodhouse, 2016).

But what about having just one object of research? Let's illuminate this transmission within one person. We call this transgenerational effect of attachment (what was I given- remembered attachment, what do I share with my partner- attachment in close relationships, what do I give to my newborn- bonding) and there are researches that have partially devoted to this effect. Between remembered attachment to 
parents and attachment in close relationships there were several weak and moderate relationships (Priel \& Besser, 2000; Rozvadský Gugová et al., 2014). Furthermore, researchers provide invincible evidence that parent representations are empirically linked to parenting (Feeney \& Woodhouse, 2016; Van Ijzendoorn, 1995) with a moderate relationship between parent attachment representations and his/her sensitivity (Feeney \& Woodhouse, 2016). There is also robust evidence that adult romantic attachment styles are empirically linked to parenting (Feeney \& Woodhouse, 2016; Priel \& Besser, 2000) with moderate negative correlations found between dimensions of anxiety/avoidance and maternal attachment toward her children (Şen \& Kavlak, 2012).

But there is little evidence that attachment transgenerational effect (what was I given, what do I share with my partner, what do I give to my newborn) within one object (mother or father) is congruent, not to mentioned that fathers are usually excluded or rather that domain of attachment is strongly matriarchal when tackling the issue of parenting. There is small effect size in remembered attachment in father's rejection, father's emotional warmth and mother's overprotection (Gugová \& Eisemann, 2016; Poliaková et al., 2007). Regarding adult romantic attachment, women are more anxious and men are more avoidant (Del Giudice, 2011; Rozvadský Gugová et al., 2014), even though that the differences are of small effect size. When talking about relationship towards own newborn, we take parent-to-infant relationship or bonding to be our conceptual frame. Bonding is a type of emotional relationship that is unique, specific, and long-lasting (Ainsworth, 2006). There are moderate differences between women and men with men stating less bonding than women (Greškovičová et al., 2018).

Considering the absence of empirical studies on the attachment transgenerational effect and exclusion of men in the parenting issues, our study aimed to explore this effect. Most of the researches rely heavily on observation of parental sensitivity therefore we chose only self-reported instruments to catch the inner world of our participants and their representations. We formulated:

RQ1 Will remembered attachment be a predictor of attachment in close relationships and bonding? RQ2 Will attachment in close relationships be a predictor of bonding?

RQ3 Will there be a difference in remembered attachment?

RH1 Women will be more anxious and men more avoidant (Del Giudice, 2011; Rozvadský Gugová et al., 2014).

RH2 Women will have higher bonding than men (Greškovičová et al., 2018).

\section{Methods}

Our sample consisted of 26 fathers and 74 mothers $(\mathrm{N}=100)$ who recently gave birth $\left(\mathrm{M}_{\mathrm{age}}=31,11\right.$, $\min 21$, max 46 years). They were approached at obstetrics and gynaecology clinic in Bratislava, Slovakia, from November 2018 till January 2019. We used 3 self-administered questionnaires: sEMBU (remembered attachment), ECR-R (attachment in close relationships), and MIBQ (bonding towards infant).

The Slovak version (Poliaková et al., 2007) of the s-EMBU by Arrindell et al. (1999) measures remembered parental rearing behaviour. 23 items are distributed into three dimensions: rejection (7 items), emotional warmth (6 items including item no. 9) and overprotection (9 items). The items are scored on a 4-point scale ranging from "no, never" to "yes, most of the time". Summary indices are computed for each dimension regarding mother and father rearing approach. Higher summary index score indicates increased dimensions. In case of missing answers ( 7 cases), we granted the participants mean scores. In our research, esteem of reliability ranged between $\alpha=.798$ and .595 for the dimensions.

The Slovak version (Bieščad \& Hašto, 2010) of the ECR-R (The Experiences in Close Relationships-Revised) by Brennan et al. (1998) is a 36-item measure of adult romantic attachment style. It consists of two dimensions (avoidant and anxiety) with 18 items in each. The items are scored on a 7-point scale ranging from "strongly disagree" to "strongly agree". Average scores are computed for both dimensions. Higher average score indicates increased avoidance/anxiety. Internal consistency for avoidance was $\alpha=.865$ and for anxiety $\alpha=.773$.

The MIBQ (Mother Infant Bonding Questionnaire) by Laohapensang (1988 in Eksirinimit, 2012) measures mother-to-infant bonding. It includes 31 items divided into 6 dimensions: perception of infant features (5 items), attention and connection to the infant (6), acceptance of the infant's individuality (5), acceptance of the parent 's role (4), preparation for nurturing the infant (7) and desire to touch or hold the infant (4). The items are scored on a 5-point scale ranging from "strongly disagree" to "strongly agree". Summary indices are computed for each dimension regarding mother and father rearing approach. Higher summary index score indicates increased dimensions. In our study, there was a low estimate of reliability in the dimension acceptance of the infant's individuality. Thus, we removed item no. 16 (After childbirth I feel like I have lost some parts of my body) to correct it. Internal consistency of MIBQ questionnaire dimensions ranged $\alpha=.493-.801$. 


\section{Results}

\subsection{Univariable analysis of variables}

Basic descriptive statistics and reliability esteems are displayed in table 1. Histograms and boxplots are available at authors. On the basis of graphs, descriptive statistics and normality tests we concluded that the variables except anxiety are all non-Gaussian distributed.

Table 1. Descriptive statistics of variables. source: authors.

\begin{tabular}{|c|c|c|c|c|c|c|c|c|c|}
\hline Remembered attachment & $\mathrm{M}$ & Mdn & Mod & SD & Min & Max & Skwe & Kurt & Range \\
\hline Father's rejection & 10.18 & 9 & 8 & 3.31 & 7 & 24 & 2.01 & 4.60 & 17 \\
\hline Mother's rejection & 10.19 & 9 & 8 & 3.08 & 7 & 22 & 1.52 & 2.33 & 15 \\
\hline Father's emotional warmth & 20.49 & 21 & 21 & 4.46 & 8 & 28 & -0.59 & 0.07 & 20 \\
\hline Mother's emotional warmth & 21.74 & 22 & 20 & 4.33 & 8 & 28 & -0.88 & 0.76 & 20 \\
\hline Father's overprotection & 18.79 & 18.79 & 15 & 3.81 & 11 & 30 & 0.33 & 0.01 & 19 \\
\hline Mother's overprotection & 20.47 & 20 & 20 & 4.14 & 11 & 30 & 0.26 & -0.37 & 19 \\
\hline Attachment in close relationships & $\mathrm{M}$ & Mdn & Mod & SD & Min & Max & Skwe & Kurt & Range \\
\hline Avoidance & 2.40 & 2.06 & 1.89 & 0.97 & 1 & 5.06 & 0.86 & -0.07 & 4.06 \\
\hline Anxiety & 2.92 & 2.89 & 2.94 & 0.83 & 1.33 & 5.17 & 0.20 & -0.25 & 3.83 \\
\hline Bonding & $\mathrm{M}$ & Mdn & Mod & $\mathrm{SD}$ & Min & Max & Skwe & Kurt & Range \\
\hline $\begin{array}{l}\text { Acceptance of the infant's } \\
\text { individuality }\end{array}$ & 16.13 & 17 & 20 & 3.39 & 4 & 20 & -1.06 & 1.19 & 16 \\
\hline Preparation for nurturing the infant & 28.41 & 29 & 31 & 4.84 & 10 & 35 & -1.67 & 3.65 & 25 \\
\hline Perception of infant features & 21.77 & 23 & 25 & 3.74 & 5 & 25 & -2.63 & 8.43 & 20 \\
\hline $\begin{array}{c}\text { Attention and connection to the } \\
\text { infant }\end{array}$ & 24.69 & 25 & 24 & 4.52 & 11 & 30 & -1.27 & 1.75 & 19 \\
\hline Acceptance of the parent's role & 15.77 & 16 & 20 & 3.25 & 8 & 20 & -0.20 & -0.95 & 12 \\
\hline Desire to touch or hold the infant & 17.36 & 18 & 16 & 2.80 & 5 & 20 & -2.62 & 9.01 & 15 \\
\hline
\end{tabular}

\subsection{Prediction of attachment in close relationships and bonding}

First, we analysed correlations and then we calculated a stepwise multiple regression to predict attachment in close relationships and bonding.

In remembered attachment and attachment in close relationships, mother's emotional warmth negatively correlated with both avoidance $(\rho=-.342)$ and anxiety $(\rho=-0.266)$. Mother's emotional warmth also proved to be a predictor for attachment in close relationships (RQ1). It predicted avoidance $(\mathrm{F}=10.917$, $\mathrm{p}<.01)$ with adjusted $\mathrm{R}^{2}=.091,(\beta=-.317 ; \mathrm{p}=.001)$. and anxiety $(\mathrm{F}=5.641 ; \mathrm{p}<.05)$ with adjusted $\mathrm{R}^{2}=.045$, $(\beta=-.233 ; p=.019)$.

With regard to remembered attachment and bonding, rejection by both parents was positively correlated with desire to touch or hold the infant $(\rho=.200, p=.046)$. Father's rejection was negatively associated with perception of infant features $(\rho=-.219, p=.029)$. There were several correlations with acceptance of the parent 's role: with father's rejection $(\rho=-.219, p=.028)$, mother's rejection $(\rho=-.285$, $\mathrm{p}=.004)$, and mother's emotional warmth $(\rho=.314, \mathrm{p}=.001)$. Acceptance of the parent's role was predicted by remembered attachment (RQ1), namely by both mother's emotional warmth (F=10.312; $\mathrm{p}<.01)$, with adjusted $\mathrm{R}^{2}=.086,(\beta=.309 ; \mathrm{p}=.002)$, and mother's rejection $(\mathrm{F}=6.325, \mathrm{p}<.05)$, with adjusted $\mathrm{R}^{2}=.051,(\beta=-.246, \mathrm{p}=.014)$.

And lastly, both avoidance and anxiety in attachment in close relationships negatively correlated with the desire to touch or hold the infant ( $\rho=-.263 /-.235$ respectively). But we did not find any significant regression model (RQ2).

\subsection{Comparison of women and men in remembered attachment, attachment in close relationships and bonding}

The statistical differences with small effect size were in the following variables:

- In remembered attachment (RQ3)- mother's rejection $\left(U=694 ; p=.032 ; \mathrm{r}_{\mathrm{m}}=.215\right)$ with men $(\mathrm{Mdn}=10)$ being more rejected than women $(\mathrm{Mdn}=9)$;

- In attachment in close relationships (RH1)- avoidance $\left(\mathrm{U}=695 ; \mathrm{p}=.035 ; \mathrm{r}_{\mathrm{m}}=.210\right)$ with men $(M d n=2,6)$ being more avoidant than women $(M d n=2,0)$, and anxiety $(U=697 ; p=.037$; $\left.\mathrm{r}_{\mathrm{m}}=.209\right)$ with men $(\mathrm{Mdn}=3.3)$ being more anxious than women $(\mathrm{Mdn}=2.8)$;

- In bonding (RH2)- preparation for nurturing the infant $\left(\mathrm{U}=621.5 ; \mathrm{p}=.006, \mathrm{r}_{\mathrm{m}}=.272\right)$ with women $(\mathrm{Mdn}=30)$ being more prepared than men $(\mathrm{Mdn}=27.5)$. 


\section{Discussion}

Transgenerational transmission is an intriguing area to study. We defined so-called attachment transgenerational effect that stands for one-object-attachment-representation transmission and we explored if by three self-reported tools (for remembered attachment, attachment in close relationships, and bonding). We formulated three research questions and two hypotheses.

We confirmed that the more avoidant and anxious participants were, the less mother's emotional warmth they felt. This relationship was moderate that is in accordance with other researchers (Rozvadský Gugová et al., 2014). Mother's emotional warmth was actually a predictor of both anxiety (5\%) and avoidance (9\%) in close relationships (RQ1), that is in line with other researches (Priel \& Besser, 2000; Rholes et al., 1995).

If the participants felt rejection by either mother or father, they wanted to touch and hold the baby more. The most important dimension in bonding was acceptance of the parent's role which was linked to mother's emotional warmth and rejection by both parents. The more mother's emotional warmth participants felt during their upbringing, the more they accepted their parent role (which could help to quicker adapt to new life event transition). On the other hand, if the participants felt rejection by either mother or father, they were less able to accept their own parent's role. With regard to predictions, mother's emotional warmth (9\%) and rejection (5\%) were predictors of how women / men accept their role as being a parent (RQ1).

Parent representations/adult romantic attachment styles are clearly associated with parenting (Benoit \& Parker, 1994; Feeney \& Woodhouse, 2016; Priel \& Besser, 2000; Şen \& Kavlak, 2012; Van Ijzendoorn, 1995) and the same was in our research, even though we found only weak (negative) relationships and only with one of the bonding dimensions (desire to touch or hold the infant). Consequently, regression analysis did not confirm prediction power of attachment in close relationships to bonding (RQ2). We explain this surprising result with the instruments. MIBQ for assessing bonding does not probably measure the attachment qualities as stated in attachment theory.

As to differences due to sex, in remembered attachment (RQ3), there was a small difference in mother's rejection with men feeling more rejected than women. No difference was found in other dimensions. Our results differ to results of other researchers (Gugová \& Eisemann, 2016; Poliaková et al., 2007), but effect size is also small. In attachment in close relationships (RH1), men were more avoidant than women, which is in the line with other researches (Mikulincer \& Shaver, 2007; Rozvadský Gugová et al., 2014), but men scored higher than women in anxiety. We interpret this difference with new family structure and family roles. Men may have changed the attitude to women as romantic partners, as men could be afraid to lose the love of their partners to a new member of the family. Men could feel rejected and abandoned since their partners were probably intensely involved in child caring and were also still at hospitals. It is possible that family structure change confirms the stability of attachment style in women and shudders it for men as suggested by Crowell et al. (2002). In exploring sex differences in bonding (RH2), we found almost medium difference in the scale of preparation for nurturing the infant with women being more prepared than men. These differences are not surprising and are in line with our previous researches (Greškovičová et al., 2018).

We see several limits among which self-reported instruments, new questionnaire MIBQ, relatively big age range of our participants, smaller sample of men are the most serious ones. Transgenerational effect is difficult to tap and our methods were potentially not the best ones in doing so. We should deliberate whether other concepts such as psychological types (Lisá, 2017) or traits (Lisá \& Kališ, 2019) are not involved in the manifested/ measured behaviours. Even though, we consider our research to be important in slightly clarifying attachment transmission and attachment transgenerational effect within one object. Based on our results and interpretations, we conclude that namely mother's emotional warmth seems to be important and helpful in creating romantic relationships as well as accepting the parent role.

The research study was created as a part of the research project GAAA 3_5/2020: Workplace attachment in the context of organizational behaviour and performance variables.

\section{References}

Ainsworth, M. D. S. (2006). Attachments and other affectional bonds across the life cycle. In C. M. Parkes, J. S. Hinde, \& P. Marris (Eds.), Attachment Across the Life Cycle (pp. 33-51). London: Routledge.

Arrindell, W. A., Sanavio, E., Aguilar, G., Sica, C., Hatzichristou, C., Eisemann, M., Recinos, L. A., Gaszner, P., Peter, M., Battagliese, G., Kállai, J., \& van der Ende, J. (1999). The development of a short form of the EMBU: Its appraisal with students in Greece, Guatemala, Hungary and Italy. Personality and Individual Differences, 27(4), 613-628. 
Behrens, K. Y., Haltigan, J. D., \& Bahm, N. I. G. (2016). Infant attachment, adult attachment, and maternal sensitivity: Revisiting the intergenerational transmission gap. Attachment and Human Development, 18(4), 337-353.

Benoit, D., \& Parker, K. C. H. (1994). Stability and Transmission of Attachment across Three Generations. Child Development, 65(5), 1444-1456.

Bieščad, M., \& Hašto, J. (2010). Diagnostikovanie typov vztahovej väzby (attachment) v dospelosti s použitím nástrojov dostupných v našich podmienkach. Psychiatrie, 14(2), 68-74.

Bowlby, J. (2010). Vazba. Teorie kvality raných vztahů mezi matkou a dítětem. Praha: Portál.

Brennan, K. A., Clark, C. L., \& Shaver, P. R. (1998). Self-report measurement of adult attachment: An integrative overview. In J. A. Simpson \& W. S. Rholes (Eds.), Attachment Theory and Close Relationships (lis, pp. 46-76). New York: Guilford Press.

Bretherton, I., \& Munholland, K. A. (2008). Internal working models in attachment relationships: Elaborating a central construct in attachment theory. In J. Cassidy \& P. R. Shaver (Eds.), Handbook of Attachment: Theory, Research and Clinical Applications (2nd ed., pp. 102-127). New York: Guildford Press.

Crowell, J. A., Treboux, D., \& Waters, E. (2002). Stability of attachment representations: The transition to marriage. Developmental Psychology, 38(4), 467-479.

Del Giudice, M. (2011). Sex differences in romantic attachment: A meta-analysis. Personality \& Social Psychology Bulletin, 37(2), 193-214.

Eksirinimit, T. (2012). A longitudinal evaluation of Kangaroo Care for preterm infants in Thailand [Electronic Thesis or Dissertation, Flinders University. School of Nursing \& Midwifery]. https://theses.flinders.edu.au/view/d11d8efe-c5d0-4d92-8009-585cc4c7d518/1

Feeney, B. C., \& Woodhouse, S. (2016). Caregiving. In J. Cassidy \& P. R. Shaver (Eds.), Handbook of Attachment: Theory, Research, and Clinical Applications (pp. 827-851). New York: Guilford Press.

Greškovičová, K., Szobiová, E., \& Zdechovanová, B. (2018). Bonding k diet’at’u u žien a mužovIndividuálna a párová analýza. In L. Sabová (Ed.), Psychologica 47 (pp. 39-46). Bratislava: Stimul.

Gugová, G. R., \& Eisemann, M. (2016). Psychometric Properties of the Slovak Version of sEMBU on General Adult Sample. Acta Educationis Generalis, 6(3), 32-43.

Hennelová, K. (2014). Biodromal psychology. Nitra: ForPress.

Lisá, E. (2017). Analysis of personality traits among psychological types. Ad Alta, 7(2), 118-122.

Lisá, E., \& Kališ, M. (2019). The psychometric characteristics of the Hexaco-100 questionnaire used in the selection and non-selection situation. Work and Organizational Psychology 2019: Proceedings of the 18th International Conference, 144-153.

Mikulincer, M., \& Shaver, P. R. (2007). Attachment in adulthood: Structure, dynamics, and change. New York: Guilford Press.

Poliaková, M., Mojžišová, V., \& Hašto, J. (2007). Skrátený dotazník zapamätaného rodičovského správania ako výskumný Shortened inventory for memories of parental rearing behaviour as a research. Psychiatria-Psychoterapia-Psychosomatika, 14(2-3), 79-88.

Priel, B., \& Besser, A. (2000). Adult attachment styles, early relationships, antenatal attachment, and perceptions of infant temperament: A study of first-time mothers. Personal Relationships, 7(3), 291-310.

Rholes, W. S., Simpson, J. A., \& Blakely, B. S. (1995). Adult attachment styles and mothers' relationships with their young children. Personal Relationships, 2(1), 35-54.

Rozvadský Gugová, G., Heretik, A., \& Hajdúk, M. (2014). Psychometric properties of the Slovak version of Experiences in Close Relationships- Revisited (ECR-R) on general adult sample. Studia Psychologica 56, 1, 37-52.

Şen, S., \& Kavlak, O. (2012). Transgenerational attachment in Manisa, Turkey. Contemporary Nurse, 41(1), 126-132.

Van Ijzendoorn, M. H. (1995). Adult attachment representations, parental responsiveness, and infant attachment: A meta-analysis on the predictive validity of the adult attachment interview. Psychological Bulletin, 117(3), 387-403.

Verhage, M. L., Schuengel, C., Madigan, S., Pasco Fearon, R. M., Oosterman, M., Cassibba, R., Bakermans-Kranenburg, M. J., \& Van Ijzendoorn, M. H. (2016). Narrowing the transmission gap: A synthesis of three decades of research on intergenerational transmission of attachment. Psychological Bulletin, 142(4), 337-366. 